\title{
Challenges and Opportunities of Expansion of Islamic Banks in Ethiopia: Case of Commercial Bank of Ethiopian Dire Dawa Interest Free Branch
}

\author{
Meka Fekadu Abdulhade \\ Dire Dawa university Department of Accounting and Finance
}

\begin{abstract}
This study assessed the challenges and opportunities of expansion of Islamic banks in Ethiopia in case of commercial bank of Ethiopia Dire Dawa interest free branch. For sake of obtaining sufficient data, the researcher mainly used primary data that would be collected through open ended and close ended questioner from employees of commercial bank of Ethiopia Dire Dawa interest free branch. In addition to questioner, interview was conducted with branch manager of Dire Dawa interest free branch and higher officials of Islamic banks in the process of establishment. The secondary data also would be gathered through document review to support the primary data. To analyze the questioner SPSS soft ware would be used. Based on the analysis and interpretations the main findings of this study was an Islamic bank have both opportunities and challenges in their expansion. The main challenges are higher computation from conventional banks that open interest free banking service in branch and window level, lack of awareness of the society regarding Islamic banks, professional skill gap regarding Islamic banks operation and lack of awareness of the society regarding Sharia based financing. The main opportunity of Islamic banking expansions are there is high demand in the market, the banking industry in Ethiopia is in growth stage and Islamic banks can mobilize more addition deposits from Muslim society which was out banking industry.
\end{abstract}

Keywords: Islamic banking, Conventional banks and Interest free banking

DOI: $10.7176 /$ RJFA/11-3-05

Publication date: February $29^{\text {th }} 2020$

\section{Introduction}

The economic development of any country depends on the existence of well-organized financial system. Financial institutions are one important components of financial system of a given country. (www.envestopedia.com). As Ethiopian financial system is bank dominated, banks are a part of those institutions which accept deposit from economic agents and then lend this funds to make direct loans or invest in security like stocks and bonds (Cambel Harvey, 2010). Banks operates by charging interest as well as operates without charging interests. Interest is fee paid for usage of others money. To the borrowers it is the cost of renting money to the lender it is income for lending the money. Islamic banks operate without charging interests (Islamic finance.com). Islamic banks are derived from Islamic world, it is fundamental concept it operate primitive professional and ethical investing while elimination of interest in all its forms is an important future of the Islamic financial system (Islamic finance.com).

According to National bank of Ethiopia Interest free banking service mean a system of banking or financial activity that is compliant with Sharia principles and guided by Islamic economics which prohibits the collection and or payment of interest as well as engaging in activities forbidden by Sharia. Interest free banking provides profit-sharing investment accounts to the depositors (www.nbe.gov.et). As National bank of Ethiopia allows for banks to provide interest free banking services with directive No-72 (2019) in branch level or as fully fledged operation, Islamic banks like Hijra bank, Zamzam Bank, Zad banks starts their formation to play their own role for development of saving and investment of the country.

Islamic banks expansion may have both opportunities and challenges and different researchers try to identify the opportunities and challenges. According to Tsion sisay (2017) Interest free banking operation has challenges like lack of sheria advisors boards, lack of awareness of customers regarding interest free banking, Lack of confidence by customers, unavailability of the service in all branches are challenges of interest free banking operation (Tsion sisay , 2017). Kerima Ali Mohammed's (2016) also stated that the challenge faced by banks to provide interest free banking service are unmet demand of users, awareness of customers and capacity of bank.

Currently both conventional banks and fully fledged Islamic banks started to establish their branches in the major cities or town of the country. In previous years according to interest free banking proclamation No. 5922008 at sub article 22(2) allows interest free banking business by window level to all commercial banks. Based on this directive almost all private and governmental banks are provides interest free banking service by window level starting 2008 G.C. Starting from 2019 G.C a new directive on interest free banking No-72 coming to operation. The new directive allows interest free banking service with full fledged Islamic bank and in branch 
level. Based on this directive conventional banks like Commercial bank of Ethiopia, Awash bank and oromia international banks started to provide this service in branch level. On the other hand fully fledged Islamic banks like Zamzam bank, Hijra bank and Zad banks are in the process of formation to provide interest free service in bank level.

Therefore as interest free banking service is started to be delivered by both conventional banks in branch level and Islamic banks in bank level, there may be new opportunities and challenges. So that the researcher interested in investigating the challenges and opportunities of expansion of Islamic banks by taking commercial bank of Ethiopia Dire Dawa interest free branch as case study.

\section{STATEMENT OF THE PROBLEM}

Financial institutions plays great role within a given countries economy by intermediating resource from lenders to borrowers. The low level of investment in developing countries largely attributed to the low level of saving, low level of job opportunity and low level of economic growth (Rodney Wilson 1986). It is unquestionable that investment plays a leading role for the growth of a countries economy but this requires the accumulation of capital and appropriate allocation of accumulated capital. Islamic bank can play their own role in capital accumulations and loan dispersement of the country. There are religious, political as well as economic reasons, which have contributed to the emergence of Islamic banks as an alternative to conventional banks in Ethiopia. The religious reason is prohibition of interest by holy Quran during borrowing and lending of money in Muslim communities (Islamic finance.com). Because of this, most of the Muslim communities have less interest to work with conventional banks or may not work totally with conversional banks. To overcome this problem the Muslim communities in Ethiopia continues to raise question regarding establishment of Islamic banks in Ethiopia. To answer the Muslim community question partially the Ethiopian government takes one important measure in 2008 G.C, with interest free banking proclamation No. 592-2008 at sub article 22(2) by allowing interest free banking business by window level.

But the Muslim community not satisfies with the government decision and continues questions regarding Islamic banks establishment. To answer fully the Muslim communities questions, Ethiopian government takes measure by allowing full-fledged Islamic bank establishment with directive on interest free banking No-72 2019 G.C. After governments decision regarding the establishment of Islamic banks, different banks are starts their establishment processes. In another way the conventional banks in Ethiopia takes this government decision as treat and started to open interest free banks in branch level to maintain their customers and to get addition customers.

Some limited studies were conducted on challenges and opportunities of interest free banking services in different parts of the world and in Ethiopia. For instance, Akmel Hailu's (2015) studied about "challenges and prospects of Islamic banking for resource mobilization in Ethiopian commercial banks. "The study focuses on challenges and opportunities of IFB only on resource mobilization other challenges and opportunities are not well addressed. Tsion sisay (2017) conducted research on challenges and opportunities of interest free banking in case of commercial banks operating in Addis Ababa. The result of this study stated that lack of awareness by customers and difficulty to segregate fund for effective implementation of IFB service. The researcher concludes that the opportunities of interest free banking are more significant than the challenges.

On the other hand Yewubedar Getachew (2018) also conducted research on challenges and opportunities of interest free banking in case of commercial bank of Ethiopia northern district. The research concludes that lack of sheriah advisors boards, lack of awareness of customers regarding interest free banking, Lack of confidence by customers, unavailability of the service in all branches are challenges of interest free banking operation. In addition Robel Demissie (2019) conducted a research on factors affecting implementation of interest free banking service in Ethiopia: the mediation role of customer involvement. The result of this research showed that awareness, comparability, complexity, observability, perceived risk; religious beliefs and customers involvement were significant on the implementation of interest free banking service.

Even though the above researches are conducted in Ethiopia in different corners of the country, they did not show the challenges and opportunities of Islamic banks expansion in Ethiopia. In addition the above researches are conducted at the time interest free banking is allowed by National bank only at window level. As currently National bank allows full-fledged Islamic bank, there may be new challenges and opportunities. So that, this research is designed to fill the above stated gaps by assessing the challenges and opportunities of expansion of Islamic banks in Ethiopia with special focus on commercial bank of Ethiopia Dire Dawa interest free branch.

\section{OBJECTIVES OF THE STUDY}

The main objective of this research would be assesses the opportunities and challenges of the expansion of Islamic banks in Ethiopia particularly Commercial bank of Ethiopia Dire Dawa interest free branch. The specific objectives of this study would be:-

- To identify the opportunities and challenges of expansion Islamic banking in Dire Dawa 
- To examine the societies motivation regarding saving and investment after establishment of branch level or full-fledged Islamic banks in Dire Dawa.

- To assess effect of expansion of Islamic banks on conventional banks

\section{RESEARCH METHODOLOGY}

For this study, the researcher would apply descriptive analysis used the fact that a descriptive research design will used to describe the data and characteristics about what will done. Descriptive survey will also enable to obtain the current information. It will also use in fact findings studies and help to formulate certain principles and give solutions to the problems concerning local or national issues. The study will use qualitative research approach. The reason for using qualitative research approach is to answer why peoples are interested on interest free banking service and this approach will be used in exploring and understanding the meaning individuals or groups ascribe to a social or human problem. The process in this approach involves emerging questions and procedures, data typically collected in the participants setting, data analysis inductively building from particular to general, and the researcher making interpretations of the meaning of data.

The researcher would collect data from employees of commercial bank of Dire Dawa interest free branch. In addition to the employees of commercial bank of Ethiopia Dire Dawa interest free branch, data would be collected from higher officials of the new full-fledged Islamic banks. The researcher would use census method to collect questioner from employees of commercial bank of Ethiopia Dire Dawa interest free branch. The number of employees of commercial bank of Ethiopia Dire Dawa interest branch is 20. The researcher prefers census method because the number of target population is less than 30. To get data from interview the researcher conducted interview with branch manager of Commercial bank of Ethiopia Dire Dawa interest free branch and higher officials of the three full - fledged Islamic banks under formation i.e. Hijra, Zamzam and Zad are selected purposely

The researcher used mainly primary data collected from questioner and interview as source of data. Questionnaires were distributed to employees of commercial bank of Ethiopia Dire Dawa interest free branch and interviews were conducted with manager of Dire Dawa interest free branch and higher officials of the three fully fledged Islamic banks. In Addition to primary data, secondary data was collected from available source of commercial bank of Ethiopia and other selected banks. The researcher used descriptive method of data analysis to draw conclusions and inferences. This descriptive type data analysis would be preferred due the nature of the analysis requires to use table, percentages are used to make comparisons and interface.

\section{Literature reviews}

Interest rate is the price paid or charged for the usage of others money. An interest rate is often expressed as annual percentages of the principal. Interest rates send price signals to borrowers, lenders, savers, and investors. Interest rate measures risk lenders demand additional compensation for lending to riskier to earn a primitive that is higher than the rate of inflation to make any transaction worthwhile (Campbell Harvey, 2012). Economic development of a given country partially depends on the financial system to help transfer of money to area of the economy that needs most (Rodney Wilson 1986).

Bank plays vital role in the development of an economy. It is a special type of organization where the credit and capital are supplied (Reilly brown, 2005). Conventional banks operate by collecting deposit from individual, business and government to pay interest and gives loan to individuals, business and governments with higher interest rate. This shows that the main source of income for conventional bank is interest income (spread between lending interest rate and deposit interest rate). Over the last forty years, there has been a rapid expansion of financial institution that can be characterized as interest free banking. Interest free banking, the more general terms, is expected not to avoid transaction based on interest but also to participate activity in achieving the goals and objectives of financial system (Rodney brown, 2005).

Financial dealing in compliance with Sharia law date back the early century of Islam, but this traditional money lending and money changing rather than commercial banking as practiced today. Modern commercial banking introduced in the majority of Muslim country with the spread of European trade during the $19^{\text {th }}$ century (http//www.finance in islam.com). There are economic and religious reasons, which have contributed to the emergence of private limited banking as an alternative to its interest charged counterpart. The economic reason derived from providing inspiration to devise an interest free financial system has been substantiated in the way that interest concentrates wealth in the hands of few. It is the prohibition of interest which traced to religious reason. The basic intention behind establishing interest free bank was desire of Muslim to recognize their financial activity in an away that do not contradict the principle of Islamic law and enable them to conduct their financial transaction without connection into interest. Thus interest free banking emerged as a response to both economic and religious factor (Taqi Usmani M. 2005).

The following countries are can be taken as exemplary for their successful Islamic banks or interest free banking operation. 


\section{Iran}

The processes of transformation of interest free banking in Iran have proceeded in the three distinct phase. Nationalization restructuring and re -organization of entire banking system characterized phase one taking place between 1979 and 1982. External and internal developments did not allow the policy makers to develop coherent plan for interest free banking system although various piecemeal attempts were made towards this objectives. The second phase began in 1986,it was a phase primary characterized by adoption of legislative and administrative steps in order to implement a clear articulated model of interest free banking The third phase which continue until now, began in 1996.This phase define the roll of interest free banking system differently from the earlier phases. The banking sector has been used an instrument to restrict Iranian economy the restriction was essentially direct the shifting financial resources from services and consumption to the production sector in four ways. First credit to the service sector second, it creates incentive for the development of cooperative sector planning agriculture industry and trade. Third the banking system in partnership with the government under takes to finance large industrial project and investment in social overhead capital. Fourth using all available model of finance to help farmers to improve and expand production encourages growth of agriculture sector (http//www.financeinislam, com).

\section{Pakistan}

Pakistan adopted a policy of gradual transformation of its banking system from February 1979, after several years of study and preparation by the government appointed council of ideology. The process started when the president of Pakistan announced that interest was to be removed from the economy with in period of 3 years. Three of specialized credit institutions are the house building corporations, national investment trust and mutual trust funds of Investment Corporation of Pakistan where to remove interest from their financing operation immediately. In June 1984 the government announced discontinuation of dual window of operation on the banking and financial system, except the foreign currency deposit which continue to earn fixed interest, where brought under non interest based modes of financing. Interest free banking in Pakistan appears to be cross road and if there to be further progress the regulatory and legal condition must be such that system will have a fair chance to perform as expected (http//www.finance in Islam .com).

\section{South Africa}

The Muslim population in South Africa is relatively small but both affluent and influential. Interest free bank was introduced in South Africa in 1989 by Alabama Antioch bank operating with a limited branch foot print. This only interest free offering until 2002 when first national bank in the country launched an interest free finance product followed by an interest free cheque account most recently interest free banking started offering its service compliant products through its branch in Botswana in 2006, Absa the largest retail bank including group in south Africa launched, the first comprehensive interest free bank offering the services like cheque account vehicle finance, transactional saving account and interest free wills. This offering was supported by the full range access support from the ATM and branch network in the country, as well as sale phones and internet banking (http//www.finance in Islam .com).

\section{Nigeria}

Nigeria with population of $140,000,000$ people is not only the most populous country in Africa but it is also the largest economy in west Africa.60 percent of Nigerian Muslims and in response to their demands to have a bank that meets their religious moral and ethical aspirations the efforts are in progress by a number of corporate bodies, individuals and Islamic organization to achieve these goal and with their regulatory frame work of interest free banking by the central bank of Nigeria in feb.2009, all is now set for jazz, the first interest free bank in Nigeria to commence full commercial operation(http//www.finance in Islam .com).

\section{Conventional and Islamic banks development in Ethiopia}

Modern banking was introduced in Ethiopia 1905. At the time, an agreement was reached in between Emperor Minelik II and a representative of the British owned National Bank of Egypt to open a bank which leads to Bank of Abyssinia launched in Feb.16, 1906 by the Emperor (Abraha and Imam, 2005). In Ethiopia, regards to interest free bank; the government is cautiously promoting the establishment of a home-grown interest free banking industry. The Ethiopian government takes one important measure in 2008 G.C, with interest free banking proclamation No. 592-2008 at sub article 22(2) by allowing interest free banking business by window level. But the Muslim community not satisfies with the government decision and continues questions regarding Islamic banks establishment. To answer fully the Muslim communities' questions, Ethiopian government takes measure by allowing full-fledged Islamic bank establishment with directive on interest free banking No.72 - 2019 G.C. After governments decision regarding the establishment of Islamic banks, different banks are starts their establishment processes. In another way the conventional banks in Ethiopia takes this government decision as 
treat and started to open interest free banks in branch level to maintain their customers and to get addition customers. The above theoretical literatures and banking history shows that Ethiopia as country uses both interest charged and interest free system co-existed like Indonesia, Malaysia, Pakistan and United Arab Emirates (Zamzam bank s.c, 2019)

\section{Empirical literature review}

As interest free banking is the recent phenomena different researchers internationally try to see this topic in different ways. Roddney Wilson, (2010) indicated that interest free banking finance has become increasingly significant in financial centers in the West, notably London, despite the regulatory hurdles presented by operating in a non-Muslim financial environment. At the same time interest free financing methods are viewed as a challenge and opportunity by Western bankers, many of whom have sought to get involved in this growing industry. In client driven societies there is willingness by those in financial services to listen and learn from the experiences of interest free banks, which in the longer run may bring a major breakthrough for interest free banking at the retail level in the West (Roddney Wilson, (2010).

Hanudin Amin, (2013) in his article of some view points of interest free banking retail deposit products in Malaysia indicated that those products were centered on the current accounts, saving accounts and investment accounts. These deposit products are examined in terms of their definitions, features and calculations. On the same note, some discrepancies between deposit facilities offered by interest free and conventional banks are exposed. The purpose of such exposition was to provide to novice readers a basic but profound explanation concerning the difference between the two categories of deposit facilities.

Abdulmajid et.al (2015) conducted research on the efficiency in interest free banking and conventional banking an international comparison investigates the efficiency of interest free banks and conventional banks using an output distance approach. Even after controlling for specific environmental characteristics both interest free and conventional banks, interest free banks are found to have high returns to scale than conventional banks. While this suggests that interest free banks may benefit from increased scale, they emphasis and the results suggest that identifying and overcoming the factors that cause interest free banks to have relatively low potential output for a given input usage levels will be the key challenges for Islamic banking in the coming decades Abdulmajid et.al (2015).

According to Ismaeil, et al. (2015) conducted a research on Islamic banks (interest free banking) as alternative banking industries. The result showed the recent development of insolvency of many conventional banks made by the Central Banks to initiate the acquisition of some banks while others were ordered to merge. This was a strong signal to seek for alternative banking system. However, the advocacy for the Islamic banking system as alternative to conventional banking system has been received with mixed feelings. He also posited that awareness, manpower, legal framework, societal belief, cash requirements were some of the challenges while economic growth, attraction of investors, and fostering of egalitarian society are the likely prospects for the establishment of the interest free banking. He concluded that interest free banking system hold a potential to transform all sectors of the economy with eradication of poverty, equitable distribution of income and employment opportunities in the country through effective mobilization and allocation of capital (Ismaeil, et al. (2015).

In Ethiopia, Interest free banking is a recent phenomenon. As a result, there is limited empirical literature on the area. The studies conducted so far include the following: Akmel Hailu's (2015) studied about "challenges and prospects of Islamic banking for resource mobilization in Ethiopian commercial banks. "The study focuses on challenges and opportunities of IFB only on resource mobilization other challenges and opportunities are not well addressed. On the other hand a research by Debebe Alemu (2015) who studied the factors affecting customers' use of IFB in Ethiopia and found out that 100\% of IFB account holders were all Muslims. Evidently, the failure of banks to meritoriously serve the Ethiopian Muslim population hinders the development of the Muslim inhabited areas in particular and the economy of the nation as a whole. This study is about impact assessment on the attitude towards IFB usage which does not address the current problem at hand.

Mohammed's (2012) study which is about "Challenges on Interest Free Banking Services" The study discuses the challenge faced by service providers and users of IFB products and scope of service provided by Ethiopian banking through IFB including whether there is unmet demand of users, awareness of customers and capacity of bank the study doesn't addressed the opportunities of interest free banking as a new business strategy in Ethiopia. Tsion sisay (2017) conducted research on challenges and opportunities of interest free banking in case of commercial banks operating in Addis Ababa. The result of this study stated that lack of awareness by customers and difficulty to segregate fund for effective implementation of IFB service. The researcher concludes that the opportunities of interest free banking are more significant than the challenges. On the other hand Yewubedar Getachew (2018) also conducted research on challenges and opportunities of interest free banking in case of commercial bank of Ethiopia northern district. The research concludes that lack of sheriah advisors boards, lack of awareness of customers regarding interest free banking, Lack of confidence by 
customers, unavailability of the service in all branches are challenges of interest free banking operation. In addition Robel Demissie (2019) conducted a research on factors affecting implementation of interest free banking service in Ethiopia: the mediation role of customer involvement. The result of this research showed that awareness, comparability, complexity, observability, perceived risk; religious beliefs and customers involvement were significant on the implementation of interest free banking service.

\section{Literature Gap}

Even though the above researches are conducted in Ethiopia in different corners of the country, they did not show the challenges and opportunities of Islamic banks expansion in Ethiopia. In addition the above researches are conducted at the time interest free banking is allowed by National bank of Ethiopia only at window level. As currently National bank allows full-fledged Islamic bank, there may be new challenges and opportunities. So that, this research is designed to fill the above stated gaps by assessing the challenges and opportunities of expansion of Islamic banks in Ethiopia with special focus on commercial bank of Ethiopia Dire Dawa interest free branch.

\section{Discussions and summaries of results}

This study used descriptive analysis method to enable to obtain the current information and to help to formulation of certain principles and give solutions to the problems concerning local, national or international issues. The results from questioner and interview analysis and interpretation by using tables, percentages and graphs are summarized as follows:

The main findings of this study was Islamic bank have both opportunities and challenges in their expansion. There is higher opportunity for expansion of the Islamic banks in Ethiopia (Dire Dawa). The first important opportunity is, there is higher demand of interest free banking service in Ethiopia (Dire Dawa). Another important opportunity of Islamic banks expansion is that as Ethiopian banking industry is on expansion or growth stage, Islamic banks can play their own role for banking sector development and for the countries development as well. The next important opportunity of Islamic banks expansion is they can mobilize more addition deposits from Muslim society which was out banking industry by believing interest free banking service by window level is not according to sharia principle. This addition deposit in banking sector can increase saving and investment in Muslim community and as well in the county.

The analysis and interpretation section also discuss in detail regarding the challenges of Islamic banks expansion in Ethiopia (Diredawa) in branch level or by fully fledged Islamic banks. One of the challenges are newly established Islamic banks may have challenges in mobilizing the required capital or it may take long time to get the full required capital. The next important challenge is that as the newly established Islamic banks becomes small in size unable to compute with other convention banks which has higher capital that provides interest free service in branch and window level and there will be higher computation between Islamic banks and other commercial banks that have interest base operation. Another key challenge is lack of awareness of the society regarding Islamic banks operation and the types of products and services given by each banks. In addition most of the customers have wrong perception regarding Islamic banks are established only to Muslim communities. The next important challenge of Islamic banks expansion in Ethiopia (Dire Dawa) is the customers do not have enough awareness regarding sharia based financing. Lastly Islamic banks expansion also may have challenges of professional skill gap regarding Islamic banks operation in Ethiopia (Dire Dawa) specifically as there is no any institution that provides training on Islamic banking industry.

Lastly the analysis and interpretation part also states the effect of Islamic banks expansion on conventional banks. The expansion of Islamic banks may affect the expansion of conventional banks because customers my shift to use Islamic banks rather than convention banks and most of the Muslim community may needs pure Islamic bank than interest free banking services provided by conventional banks. In addition, the new Islamic banks may bring new form of products and services to society this may motivate the society to shift to use more Islamic banks.

\section{Conclusions and Recommendations}

The major aim of this study was to identify the major opportunities and challenges of expansion of Islamic banks in Ethiopia specifically in Dire Dawa. Based the findings the following conclusions are made:

* There is higher opportunity for expansion of the Islamic banks in Ethiopia (Dire Dawa).

* There is higher demand of interest free banking service in Ethiopia (Dire Dawa).

* As Ethiopian banking industry is on expansion or growth stage, this is good opportunity for Islamic banks to play their own role for banking sector development and for the countries development as well.

\& Islamic banks can mobilize more addition deposits from Muslim society which was out banking industry this can increase saving and investment by Muslim community and as well in the county.

* The newly established Islamic banks may have challenges in mobilizing the required capital or it may take long time to get the full required capital. 
* The newly established Islamic bank becomes small in size and unable to compute with other convention banks.

* There will be higher computation between Islamic banks and other commercial banks that have interest base operation.

* lack of awareness of the society regarding Islamic banks operation and the types of products and services is one challenges of expansion of Islamic banks in Ethiopia(Dire Dawa)

* Most of the customers have wrong perception regarding Islamic banks are established only to Muslim communities.

\& Lack of enough awareness regarding sharia based financing is one of the challenges of expansion of Islamic banks in Ethiopia (Dire Dawa).

* Professional skill gap regarding Islamic banks operatio is another challenges of expansion of Islamic banks in Ethiopia(Dire Dawa)

\& The expansion of Islamic banks have affect on the profitability of conventional banks because customers may shift to use Islamic.

Based on the research findings of the study possible recommendation were made as follows:

$>$ The newly opened Islamic banks and interest free branches should prepare different awareness creation programs and advertisement packages to create good awareness regarding Islamic banks operation and their products and services.

$>$ To increase the society's awareness and knowledge regarding Sharia based financing and Islamic banks usage, there should be strong Sharia board and each Sharia boards should advices the bank managements to prepare different awareness creation programs and should follow proper implementation each programs.

$>$ Banks themselves, Various higher institutions and training centers should prepare short term and long term trainings to fill Professional skill gap regarding Islamic banks operation in Ethiopia(Dire Dawa)

$>$ The newly established Islamic banks should make maximum effort to mobilize enough capital and to make their banks big enough to compute with existing conventional banks

$>$ To bring unbanked Muslim societies resource to banking industry both conventional banks and fully fledged Islamic banks should open branches with detail investigations and enough feasibility studies.

$>$ As Islamic banking industry can contribute its own role to increase saving mobilization, loan provision and increasing of investment in the country, National banks of Ethiopia should gives enough focus regarding the supervision of this sector.

\section{REFERENCE}

1. Abdulmajid et.al (2015), efficiency in Islamic banking and conventional banking: an international comparison, university of Kebangsaan Malaysia

2. Abraha S.L \& Imam S.H. (2005), Dashen Bank as an Information Infrastructure, First

Deliverable: INF5210.

3. Akmel Hailu (2015). challenges and prospects of Islamic banking for resource mobilization in Ethiopian commercial banks (unpublished project paper)

4. Cambel Harvey, 2010,Hypertextual finance glossary, University of Duke

5. Debebe Alemu (2015). Factors Affecting Customers' to Use Interest Free Banking in Ethiopia (unpublished project paper)

6. Hanudin Amin, (2013), Some Viewpoints of Islamic Banking Retail Deposit Products in Malaysia, Lecturer, University Malaysia Sabah

7. Ismaeil, et al. (2015), Conventional bank and Islamic bank as institutions: similarity and difference, university of Kebangsaan Malaysial

8. Kerima Ali (2016). Challenges on Interest Free Banking Services: The Case of Commercial Bank of Ethiopia (unpublished project paper)

9. Mohammed, M (2012), "Islamic banking: Prospects, opportunities and challenges in Ethiopia", An MBA Thesis submitted to Addis Ababa University, Department of Accounting and Finance.

10. Mufti Mohammed Talisman (1998), introduction to Islamic finance.

11. National Bank of Ethiopia, (Various years' Annual reports),www.nbe.gov, Addis Ababa, Ethiopia.

12. National Bank of Ethiopia (2016). Annual Report NBE 2015/16.

13. Nobel Demissie (2019), factors affecting the implementation of interest free banking service in Ethiopia: the mediation role of customer involvement. Thesis submitted to Addis Ababa university college of business and economics department of MBA

14. Reilly Brown (2005), interest free microfinance

15. Roddney Wilson, (2010), Islamic banking and finance in European union, university of Durham and INCEIF 
16. Rondney Wilson, (1986), challenges and opportunities of Islamic banking and finance, university of Durham and INCEIF

17. Taqi Usmani, M. 2005 Introduction to Islamic Finance Pakistan: Maktaba Ma'Ariful Qur'an.

18. Tsion sisay (2017), Challenges and opportunities of interest free banking in Ethiopia .A Thesis submitted to the Department of Accounting and Finance for the fulfillment of the requirements of the Degree of Master of Science in Accounting and Finance

19. Yewubedar Getachew (2018), Assessment of prospects and challenges of interest free banking in Ethiopia in the case of commercial bank of Ethiopia, north addis district

20. Zamzam bank s.c, 2019, Zamzam Bank foundation and challenges passed, feasibility study prepare with higher officially of ZamZam bank.

\section{Electronic references}

1. http//: www. finance in islam.com

2. http//www.orointbank.net

3. http//: www.envestopedia.com

\section{Appendix}

\section{Questioner for employees of Commercial bank of Ethiopia Dira Dawa interest free branch}

Part one: Background Information

Dear respondents, please label a characteristic that correspondent to your background data by using "J" mark.

1.1 Educational Level:

Diploma and below $\square$ First degree $\square$ Masters Degree and above

1.2 Current Job Position in the bank:

Customer officer $\square$ assistant Branch manager $\square$ Accountant and Auditor

1.3 Banking Experience in number of years:

Up to 5 years $\square$ 6-10years $\square$ More than 10 years

1.4 Exposure to Interest frees banking:

Before 1 year $\square$ 1-5 year $\square$ More than 10 years year

\section{Part Two: Opportunities, challenges and awareness}

This part is divided in to three sections; in each section three statements which address issue about the bank's opportunity of Islamic banks, challenges of Islamic banks and Awareness of the society regarding Islamic banks. Therefore, please read each of the statements in each section and rate your level of agreement or disagreement with each statement by using a tick mark "J" one of the five alternatives.

\section{Opportunities of Islamic bank expansion}

\begin{tabular}{|c|c|c|c|c|c|}
\hline & $\begin{array}{l}\text { Strongly } \\
\text { dis-agree }\end{array}$ & $\begin{array}{l}\text { Dis- } \\
\text { agree }\end{array}$ & Neutral & Agree & $\begin{array}{l}\text { Strongly } \\
\text { agree }\end{array}$ \\
\hline $\begin{array}{l}\text { 1. There is higher opportunity for expansion of Islamic } \\
\text { banks in Ethiopia (Dire Dawa) }\end{array}$ & & & & & \\
\hline $\begin{array}{l}\text { 2. There is higher Demand for interest free banking } \\
\text { service in Ethiopia(Dire Dawa) }\end{array}$ & & & & & \\
\hline $\begin{array}{l}\text { 3. Interest free banking service provided by full } \\
\text { banking operation is more preferable than interest } \\
\text { free service provided in branch or window level }\end{array}$ & & & & & \\
\hline $\begin{array}{l}\text { 4. Islamic banking industry is the matured business in } \\
\text { Ethiopia (Dire Dawa) }\end{array}$ & & & & & \\
\hline $\begin{array}{l}\text { 5. The establishment of full-fledged Islamic banks } \\
\text { motivates the society for saving and investment? }\end{array}$ & & & & & \\
\hline
\end{tabular}

2. Challenges of Islamic bank expansion

1. Newly established Islamic banks unable to mobilize the required minimum capital by selling share to the market

2. Newly established Islamic banks becomes small banks and unable to compute with other commercial banks that provide interest free service in branch level and window level

3. Lack of awareness of the community regarding Islamic bank may have negative effect on expansion of Islamic banks

4. There will be higher computation between the new Islamic banks and other commercial banks that provide interest free service in branch and window level

5. The establishment of full-fledged Islamic banks affect the conventional banks profitability

6. Professional skill gap regarding Islamic bank operation may effects their expansion 
3. Customer awareness level about Islamic banks and Interest free banking products and services

1. Customers have awareness about the major types of interest free banking products.

2. The customers Knows that Interest free banking products are offered to Muslim and non Muslim users.

3. Customers know clearly regarding sheria's based financing

Part three: Open ended question

1. Please list down the type of products that are frequently requested by customers but not provided by your branches?

2. What are the challenges that interest free banking product users face?

3. Do you think your bank (branch) has challenges to provide interest free banking services? Yes

4. If you answer for question no 3 is yes, please list some of the challenges

5. Do you think your bank (branch) has good opportunities to become profitable by providing interest free banking services? Yes

\section{No}

6. If you answer for question no 5 is yes, please list some of the challenges

7. If you have any opinion or comment regarding the opportunity and challenges of Islamic banking expansion in branch level and as fully fledged Islamic banks in Ethiopia (Dire Dawa)?

Thank your co-operation 